\title{
Um ovo azul e outro rosa: pedagogia Kinder e a construção visual dos gêneros e das infâncias
}

\author{
JOÃO PAULO BALISCEI \\ ELIANE ROSE MAIO \\ GEIVA CAROLINA CALSA
}

\section{Resumo}

Em 2013, a marca Kinder lançou produtos nas versões "azul" e "rosa", com as palavras "meninos" e "meninas" estampadas em sua embalagem. Quais as representações que o Kinder Ovo cria sobre masculinidade e feminilidade? Para discutir sobre essa temática, realizamos uma pesquisa documental e bibliográfica, cujo objetivo é problematizar a constituição de gênero pelas representações e discursos promovidos por artefatos culturais infantis. Utilizamos o Image Watching para investigar o corpus da pesquisa, integrado por 13

Palavras-chave: Educação, estudo da Cultura Visual, Estudos Culturais imagens do que aqui chamamos de "Pedagogia Kinder", a qual apresenta às crianças pós-modernas modos restritos de viverem suas infâncias e suas identidades de gênero. 


\title{
A blue egg and other pink: Kinder's pedagogy and visual construction of gender and childhoods
}

\author{
JOÃO PAULO BALISCEI \\ ELIANE ROSE MAIO \\ GEIVA CAROLINA CALSA
}

\begin{abstract}
In 2013, the Kinder brand launched products in versions "blue" and "pink" with the words "boys" and "girls" printed on their packaging. What representations does the Kinder egg create about masculinity and femininity? To discuss this issue, we performed a documentary and bibliographical research, which the aim is to discuss the establishment of the gender representations and discourses promoted by children's cultural artifacts. We use the Image Watching to investigate the corpus of research. It consists of 13 images of what here we call "Kinder's Pedagogy" which features to the postmodern children restricted ways to live their childhoods and their gender identity.
\end{abstract}

Keywords:

Education, study of Visual Culture, Cultural Studies 


\title{
Un huevo azul y otro rosado: pedagogia Kinder y la construcción visual de los géneros y las infancias
}

\author{
JOÃO PAULO BALISCEI \\ ELIANE ROSE MAIO \\ GEIVA CAROLINA CALSA
}

\section{Resumen}

En 2013, la marca Kinder lanzó al mercado productos en las versiones "azul" y "rosado", con las palabras "niños" y "niñas" impresas en sus etiquetas. ¿Cuáles son las representaciones que la marca Kinder Huevo crea sobre masculinidad y femineidad? Para discutir ese tema, desarrollamos una investigación documental y bibliográfica, cuyo objetivo es problematizar la construcción de género a través de representaciones y discursos promovidos por artefactos culturales infantiles. Usamos el Image Watching para pesquisar el corpus de la investigación, constituido por 13

Palabras-clave: Educación, estudio de la cultura visual, Estudios Culturales imágenes de lo que aquí llamamos "Pedagogía Kinder", que les presenta a los niños pos-modernos formas limitadas para que vivan sus infancias y sus identidades de género. 


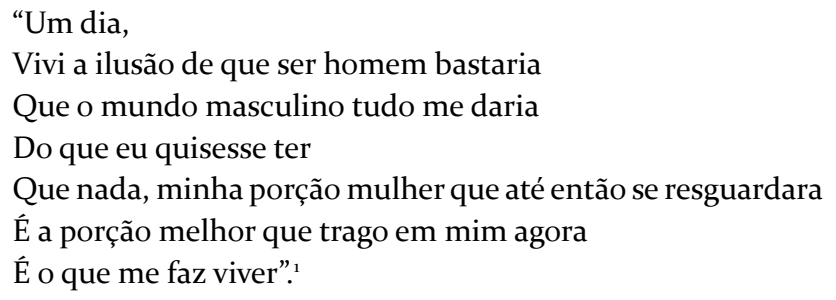

\section{Pedagogia do disfarce}

Refletir sobre a construção dos gêneros e as Pedagogias Culturais que contribuem para que eu me situe e seja situado como homem, requer, para início de conversa, que $\mathrm{eu}^{2}$ me dobre sobre mim mesmo, que eu "[...] pense sobre tais dobras e encontre formas e forças de linguagem adequadas para descrevê-las, de maneira tal que outras/os possam ter uma razoável visão de seus territórios [...]" (CORAZZA, 2007, p.104). Dentre muitos modos, o mais eficaz que encontrei para vasculhar minhas experiências com o que hoje não me satisfaz, com o que me incomoda, foi relatando aspectos de minha infância, entendendo-os como fundamentais em minha masculinidade, em minha subjetividade e em meu olhar de pesquisador.

Na década de 1990, quando vivi minha infância, já anunciava perambular entre as fronteiras de gênero me identificando ora com brinquedos, temáticas, jogos e cores socialmente atribuídas aos meninos, ora com aquelas atribuídas às meninas. Sendo o filho do meio, os mundos masculinos e femininos nos quais residiam, respectivamente, meu irmão mais velho e minha irmã mais nova, contribuíram para minha oscilação em movimentos de zigue-zague que borravam contornos sólidos, construídos pela cultura, religião e escola. 
Diferente dos outros meninos de minha idade com os quais convivia, eu era encantado pelo mundo feminino e por tudo aquilo que ele me oportunizava. Os cheiros, sons, imagens, gostos e texturas que me eram proporcionados por meio dos objetos e falas das mulheres que me rodeavam aguçavam meus sentidos e meus desejos de maneiras lúdicas e ao mesmo tempo proibidas. Consequentemente, esse encanto e favoritismo pelas mulheres se refletiram nos modos como toquei e fui tocado pela infância e pela educação escolar. Preferia as bonecas e as sereias aos super-heróis; os livros de colorir e os estojos de lápis de cor aos carrinhos e caminhõezinhos; o cheiro dos papéis de cartas e a sensação ao manuseá-los em detrimento às chuteiras, bolas e traves; as aulas de Educação Artística3 às de Educação Física, e assim por diante.

Mesmo criança, percebia que as pessoas, principalmente os homens, reagiam com estranhamento aos meus gostos e ações. Percebia que, se não proibido, era ao menos inadequado e inapropriado combinar elementos e características (ainda que qualidades) de gêneros diferentes. Era - e ainda é - conveniente que os contornos que segregam homens/meninos e mulheres/meninas, e seus respectivos papéis na sociedade, fossem mantidos estáveis, bem demarcados e, principalmente, invioláveis.

Diante disso, uma das estratégias pensadas para viver minha masculinidade sem abrir mão dos encantamentos pelo feminino foi "mascarar" e simular minhas escolhas e brincadeiras, o que chamo aqui de Pedagogia do Disfarce. Não brincava de casinha, pois "homens não brincam de casinha". "Homens são chefes de cozinha" e, portanto, brincava de restaurante e assim podia cozinhar e arrumar a mesa. Não colecionava adesivos e imagens já que "homens não são sensíveis e delicados" pois "homens são criativos". Assim, produzia e colecionava meus próprios desenhos e neles eu podia criar e colecionar o que quisesse. Não comprava ou lia revistas de moda afinal, "homens não entendem", e o mais importante, "homens não se preocupam com a aparência e com tendências de moda". Brincava, então, de editar fotos e imagens no computador e com o mouse alterava as cores dos olhos, da boca e das roupas das pessoas. Não brincava de maquiagem e de salão de beleza, pois, definitivamente, naquela época esses não eram atributos masculinos. Demonstrava apreço pela cultura do rock - e por isso era possível manifestar meus interesses por tatuagens, correntes de metal e cortes de cabelo ousados. 
Em uma infinitude de exemplos que aqui poderiam ser dados, o que quero ressaltar é que, fazer-me homem e mostrar-me homem dependiam "[...] das marcas, dos gestos, dos comportamentos, das preferências e dos gostos que [me] eram ensinados e reiterados, cotidianamente, conforme normas e valores de uma dada cultura" (LOURO, 2008, p. 17). Por isso, para garantir e legitimar minha masculinidade e minha macheza publicamente, conscientemente ou não, fiz uso de Pedagogias do Disfarce.

Considero-as como pedagogias, pois, se brincadeiras, escolhas, gostos, comportamentos e ações são dissimuladas para evitar repressões, castigos e reprovações, ainda que involuntariamente, está sendo legitimado e validado um grupo restrito de "modos de ser e viver" no mundo, desqualificando outros. Quando um único modo de ser é apontado como o modelo, ao mesmo tempo em que é fortalecido e naturalizado como "a norma", os demais modos de se posicionar e ser posicionado na sociedade são considerados desvios. Disfarçar não implica desenvolver, conscientemente e pragmaticamente, uma técnica, um método ou tática de manipulação. Nem desempenhar com engenho e astúcia capacidades transcendentais. Não é isso.

Neste artigo, entendo a Pedagogia do Disfarce primeiro como um complexo de habilidades de regular e ajustar a si próprio frente aos julgamentos, críticas e desaprovações sociais e, segundo, como um fenômeno que reflete os poderes e as opressões exercidos pela e na cultura. A manifestação desses movimentos que aqui conceituo como Pedagogia do Disfarce demonstra o poder que as visualidades têm ao legitimar comportamentos supostamente "corretos" e apontar outros que, por serem avaliados como "desvios", precisam ser corrigidos. Com isso, reconheço que mesmo evitando o sofrimento imediato daqueles/as cujos comportamentos se diferenciam da hegemonia, a Pedagogia do Disfarce opera em favor da autenticação de modelos e no silenciamento e invisibilidade das diferenças, perdurando assim hierarquias e assimetrias sociais.

Para elucidar o título desse artigo e corroborar o modo como as Pedagogias do Disfarce constituem os indivíduos no que tange à construção dos gêneros, recorro a uma memória de meu imaginário infantil: a aquisição de Kinder Ovo - o chocolate com brinquedo da marca Kinder. Desde minha infância até hoje, o Kinder Ovoéreconhecidoe desejado pelas crianças, principalmente em função do brinquedo que acompanha/compõe 
o produto: carrinhos, estátuas, quebra-cabeças, adesivos, miniaturas, bonecas, aviões, trens, animais, casinhas, flores e bruxas. Essas e outras personagens fantásticas e colecionáveis surpreendiam meninos e meninas quando abriam a cápsula de plástico que os/as "esperava" dentro do ovo de chocolate ${ }^{4}$. Particularmente, esse produto me atraía, pois não fazia distinção entre meninos e meninas - pelo menos não no que diz respeito à distribuição dos brinquedos, afinal, eram "surpresas". Tantas foram as vezes que comemorei ao ser surpreendido por um brinquedo que, talvez, em outras situações, não poderia adquirir já que era considerado "de menina”. É como se o Kinder Ovo me respaldasse para brincar com objetos de meu desejo.

Nessa linha de raciocínio, adquirir um Kinder Ovo e consumir um brinquedo culturalmente atribuído às meninas foi, para mim, uma alternativa à Pedagogia do Disfarce, já que a impossibilidade de escolher o brinquedo e o fator "surpresa" contribuíram para que a imagem de um menino brincando com bonecas, casinhas e aquarelas não causasse (tanto) estranhamento.

Ocorre que, desde o ano de 2014, em idas ao supermercado, verifiquei a existência de novas versões do Kinder Ovo. Dentre elas, uma "para meninos" e outra "para meninas". O mesmo produto que, anteriormente, projetou expectativas para que eu, pelo menos momentaneamente, usufruísse de minha infância livre dos ferrolhos que trancam e segregam os gêneros em mundos separados e distantes, agora limita e evidencia os espaços e papéis que meninos e meninas "precisam" ocupar. Que distinções entre "ser homem" e "ser mulher" são marcadas por uma pedagogia que denominamos aqui como Pedagogia Kinder? Em que aspectos os brinquedos oferecidos aos meninos são diferentes daqueles recomendados às meninas? A embalagem desses produtos insinua assimetrias entre os gêneros? Esse artefato contribui para que eu constitua minha masculinidade? Como percebo e sou percebido enquanto homem por esse produto? Esses e outros questionamentos intervêm como provocações que nos auxiliam a balizar o problema que rege esse artigo: Quais as representações que o Kinder Ovo cria sobre masculinidade e feminilidade?

Para discutir sobre essa temática, realizamos ${ }^{5}$ uma pesquisa documental e bibliográfica, cujo objetivo é problematizar a constituição de gênero pelas representações e discursos promovidos por artefatos culturais infantis. Fizemo-lo a partir dos estudos de gênero, dos Estudos Culturais e do Estudo da Cultu- 
ra Visual, campos de discussões que nos motivam a desconfiar do nosso próprio olhar e das primeiras inferências que fazemos sobre os artefatos culturais. Conforme Veiga-Neto (2007, p. 33) "[...] como já nascemos mergulhados no mundo da cultura, tomamos a linguagem como um recurso natural e de modo não problematizado, ignorando as regras segundo as quais os discursos se formam e se articulam". Para o autor, como pesquisadores/as dos fenômenos visuais, precisamos desmitificar e desestabilizar concepções naturalizadas. Duvidar da superficialidade, das aparências e do que nos é apresentado imediatamente são vanguardas do exército de pesquisadores e pesquisadoras dos Estudos Culturais, no qual podemos incluir o autor.

Quanto à estrutura, organizamos este artigo da seguinte maneira: primeiramente argumentamos sobre as crianças pós-modernas (MOMO; COSTA, 2010) e os modos como os artefatos culturais e as visualidades cotidianas constroem modelos de viver as infâncias. Também relacionamos o conceito de Cultura Visual (HERNÁNDEZ, 2007) e Pedagogias Culturais (STEINBERG; KINCHELOE, 2001) evidenciando o modo como as imagens construídas pelas corporações e empresas contribuem para a formatação e manutenção de nossa identidade.

Em um segundo momento, apresentamos os conceitos de gênero que subsidiam nosso artigo (BRAGA, 2010; BRASIL, 2011) e destacamos as visualidades como mecanismos de aprovação ou desaprovação dos modos de se viver as masculinidades e feminilidades (JUNQUEIRA, 2013; LOURO, 2000; 2008; MORENO, 2011). Discutimos sobre materiais escolares, propagandas televisivas e desenhos infantis que insinuam posições exclusivas aos meninos e às meninas, separadamente.

No terceiro tópico de nossa discussão, apontamos características históricas e culturais do Kinder Ovo e analisamos documentos produzidos pela empresa, assim como embalagens e publicidades do produto. Entendendo por documentos qualquer registro histórico, como fotos, músicas, ilustrações, filmes, sites (EVANGELISTA, 2008) e que vivemos em um "[...] mundo das imagens e do espetáculo" (MOMO; COSTA, 2010, p. 969), em nossa análise, demos prioridade, sobretudo, às imagens que alicerçam o que aqui chamamos de Pedagogia Kinder.

Por último, tecemos nossas considerações finais e evidenciamos a necessidade de produções e desdobramentos de pesquisas científicas que se preocupem efetivamente em perceber como olhamos e somos olhados/as pelas imagens corporativas do cotidiano que afetam tanto crianças quanto adultos/as. 


\section{Cultura Visual, Pedagogias Culturais e infâncias pós-modernas}

Muito do que somos, do modo como agimos, das escolhas que fazemos e dos pensamentos que formulamos sofre influência das imagens da cultura popular. Para os Estudos Culturais, nossa vertente teórica, a cultura popular não caracteriza exclusivamente as produções artesanais e folclóricas, mas também os artefatos culturais de fácil acesso, como as imagens nas revistas, nos materiais escolares, cinemas, outdoors, catálogos de moda, propagandas publicitárias, televisão, sites e redes sociais, que são tão quistas e acessíveis às crianças contemporâneas (CUNHA, 2014).

Chamados de artefatos da Cultura Visual, tais imagens contribuem para a estruturação de nossa identidade e do modo como percebermos os/as outros/as, o mundo e os papéis que desempenhamos nele. O conceito de Cultura Visual teve destaque nos últimos anos da década de 1980, em debates interdisciplinares que estabeleceram associações entre saberes distintos, vinculados aos estudos cinematográficos, à História da Arte, à linguística, aos estudos do meio e à literatura relacionados com os Estudos Culturais (HERNÁNDEZ, 2000; 2007).

Cunha (2008, p.108, grifo da autora) analisa que desde a publicação "[...] em 2000, do livro de Fernando Hernández, Cultura Visual, mudança educativa e projeto de trabalho, convivemos com a expressão Cultura Visual no contexto educacional”. A autora considera ser esse um campo relativamente jovem nos estudos, principalmente no que tange às pesquisas e publicações nacionais. Em âmbito nacional, percebemos a influência das pesquisas de Fernando Hernández sobre o Estudo da Cultura Visual nos trabalhos de autores/as, como Cunha (2008; 2011; 2012; 2014); Oliveira (2005); Martins (2005); Nunes e Martins (2012) e Nunes (2010). O Estudo da Cultura Visual, por sua vez, é entendido como um campo de estudos recente que dialoga acerca da construção do visual nas mídias, na arte e no cotidiano.

A partir do campo de investigação que é o Estudo da Cultura Visual, podemos afirmar que as imagens ensinam e exercem pedagogias e orientam pensamentos e ações. Steinberg e Kincheloe (2001) argumentam que o conceito de Pedagogia Cultural nos permite reconhecer e observar os ensinamentos propagados por outras instâncias que não a escola. Segundo a autora e o autor, na pós-modernidade as mais eficientes formas de ensinar modos de pensar e viver não são desenvolvidas e exe- 
cutadas no interior das escolas, pelos professores e professoras, mas sim pelas corporações produtoras de cultura infantil que, por meio de suas mercadorias, imagens e espetáculos, formatam e ajustam as crianças contemporâneas. As pesquisadoras e pesquisadores que compartilham do conceito de Pedagogias Culturais discutem "[...] questões e práticas partindo das artes visuais, do corpo, da performance, do funk, do cinema, dos brinquedos, dos games e, ainda, da escola ou de lugares como shopping centers, ruas e praças (TOURINHO; MARTINS, 2014, p. 12-13). Em nossas vivências acadêmicas, por exemplo, a preocupação e a problematização das Pedagogias Culturais têm se manifestado em estudos que investigam os discursos e visualidades intrínsecos aos manequins de shopping center (SOUZA; BALISCEI; TERUYA, 2015) ao padrão de beleza valorizado pela boneca Barbie (BALISCEI; STEIN, 2015), às personagens da Disney (BALISCEI, 2015) às tatuagens e marcas corporais (BALISCEI; STEIN; CHIANG, 2015) e às publicidades voltadas ao público masculino (BALISCEI; TERUYA; STEIN, 2015).

Compreender essas e outras imagens da cultura popular como Pedagogias Culturais implica reconhecer a ascensão de seu potencial educativo em relação às pedagogias desenvolvidas pelas ações escolares. Diferente dos meninos e meninas de outras épocas, as crianças contemporâneas, chamadas por Momo e Costa (2010) de Crianças Pós-Modernas, constroem e interagem com conhecimentos de modo multimídia, valorizando, sobretudo, o descarte, o espetáculo e as visualidades. Isso porque na pós-modernidade, as "[...] crianças e jovens valorizam a rapidez e o descartável, ou seja, o que foi feito para 'usar e jogar fora', em detrimento do que é duradouro, rígido e tradicional" (TERUYA, BALISCEI; NASCIMENTO, 2015, p.115). O consumo e o descarte das e pelas visualidades se tornaram duas das principais ondas que movimentam e motivam as crianças pós-modernas a surfarem em mundos líquidos.

As crianças que são visíveis, valorizadas, credenciadas em seu universo são aquelas que conseguem portar determinados artefatos, cujos significados repercutem em escala global, com vigência temporária no panorama constantemente renovado da cultura do consumo. [...] Observamos que mesmo uma criança que não tem saneamento básico em casa é capaz de saber detalhes sobre o uso e o funcionamento de notebooks, celulares e iPods tanto quanto adultos ou quanto crianças de condições econômicas privilegiadas (MOMO; COSTA, 2010, p. 976). 
Reproduzir bordões de personagens televisivos/as, colorir as unhas e os cabelos, customizar o uniforme, fotografar cenas cotidianas e compartilhá-las nas redes sociais e engenhar tatuagens provisórias com adesivos ou canetas esferográficas são algumas das estratégias da criança contemporânea que integra a denominada Infância Pós-moderna (MOMO; COSTA, 2010; STEINBERG; KINCHELOE, 2011). Esses exemplos demonstram algumas das táticas que a criança pós-moderna desenvolve para modificar constantemente seu corpo e para evitar seus maiores sofrimentos - passar despercebida, ser esquecida ou, pior ainda, viver no anonimato.

É também por meio das visualidades que as crianças pós-modernas selecionam seus/suas pares, excluindo aqueles/as que não cobiçam e que não se ocupam dos padrões compartilhados e valorizados popularmente. Inclusive nas salas de aulas - espaços aos quais Momo e Costa (2010, p.12) se referem como "palco escolar" - os/as estudantes se aproximam e imitam aqueles/as que ostentam objetos cobiçados e cujo visual é coerente com as tendências da moda. Schor (2009) afirma que muito cedo, mesmo antes de completarem quatro anos de vida, as crianças pós-modernas demonstram acreditar que a aquisição e consumo de produtos específicos lhes garantem qualidades e valores. É como se o fato de adquirem tênis ou roupas de determinada marca assegurasse-lhes como descolados/as, populares e interessantes. Essas questões ultrapassam as fronteiras de classes e são refletidas também nas práticas e comportamentos de crianças e famílias pobres, como explicam Momo e Costa (2010).

Em uma sociedade de consumo, como já mencionamos, todos devem ser considerados potenciais consumidores, e as lógicas do mercado devem atingir, inclusive, as crianças pobres. Por meio da mídia, a maioria das crianças, pelo menos as que vivem nos centros urbanos, tem sido atingida. [...] Para fazer parte dessa cultura [a do consumo, as crianças] conseguiam, de forma criativa, solucionar problemas relativos à falta de dinheiro. (MOMO, 2015, p.102, grifo nosso)

Na citação da autora destacamos "as formas criativas" que meninos e meninas buscam para consumirem, e assim, serem incluídos/as nos grupos. Construir com papel, cola e fita adesiva versões de brinquedos que estão na moda; compor pequenas sociedades, juntando dinheiro para comprar e completar coleções de figurinhas; e fazer uso de objetos, roupas e materiais es- 
colares descartados são algumas das estratégias desenvolvidas pelas crianças para que se sintam pertencentes à sociedade do consumo (MOMO; COSTA, 2010; MOMO, 2015).

Assim como constroem representações de infâncias, de beleza, de corpo ideal e de popularidade, os artefatos da Cultura Visual reproduzem e validam comportamentos tidos como femininos e masculinos. Ditam como meninos e meninas "devem" pensar, agir e se vestir, ao mesmo tempo em que supervisionam e desaprovam aqueles/as que demonstram estilos de vida diferentes. Como as Pedagogias Culturais vigiam e ajustam os corpos masculinos? Quais características e capacidades são atribuídas às meninas? Quais condutas são legalizadas e quais aquelas que precisam ser ajustadas? No item seguinte, problematizamos essas e outras questões de gênero, relacionando-as com as pedagogias exercidas nas e pelas visualidades.

\section{Visualidades e gênero: imagens que constroem modos de ser homem e mulher}

Masculinidades e feminilidades são compreendidas como transitórias, incompletas e em constante transformação, uma vez que às mulheres e aos homens são atribuídas funções e entendimentos diferentes de acordo com a época, espaço e cultura em que vivem. Conforme Braga (2010), os debates sobre gênero assinalam que as diferenças entre homens e mulheres ultrapassam as ordens biológicas e físicas, e avançam para os territórios culturais.

Com isso, compreendemos que ser mulher ou ser homem não se trata de um fato inaugural, único, isolado, como o nascimento. Louro (2008, p. 22) argumenta que "Não, a diferença não é natural, mas sim naturalizada. A diferença é produzida através de processos discursivos e culturais. A diferença é 'ensinada'. A partir desse raciocínio, ninguém nasce mulher, ninguém nasce homem. Tornamo-nos mulheres e homens conforme nos posicionamos e somos posicionados/as no mundo, uma vez que os gêneros, assim como os corpos, são significados e transformados pela e na cultura. Cultura esta que vem produzindo representações de que os homens precisam ser viris e desempenhar sua sexualidade exageradamente. Nessa lógica, quanto mais parceiras ${ }^{6}$ tiverem, e quanto mais transitórias forem, maiores serão a popularidade e $o$ reconhecimento dos indivíduos masculinos entre seus pares. Além dessas características, profissionalmente, espera-se dos 
homens que sejam bem sucedidos, poderosos e que construam uma carreira ambiciosa e ascendente capaz de garantir o sustento de suas famílias. Presume-se que o equilíbrio, a razão - e não o sentimento - balizem suas decisões.

Compreendemos a construção dos gêneros como um processo inacabado e que é interpelado por instâncias sociais consolidadas, como a religião, a família, a política e a escola. Louro (2000; 2008) avalia que, por mais que os ensinamentos e orientações dessas instituições pareçam soberanas na sociedade, estando sob condições pós-modernas, precisamos nos atentar às novas formas de interpelação como as novelas, a televisão, o cinema, a publicidade, a internet e as revistas que atuam como guias especialistas em produzir e corrigir os gêneros. Como constatação dessa interpelação, Baliscei, Teruya e Stein (2015, p. 102) evidenciam aproximações entre os discursos de masculinidade construídos em dois comerciais de automóveis. Os discursos publicitários em questão,

[...] enfatizam a necessidade do destaque social, sucesso profissional, boa aparência e confiança. Para que isso aconteça, sugerem características físicas e ações específicas (ser branco, jovem, vestir-se formalmente, trabalhar em escritórios, desempenhar determinadas funções e possuir determinados modelos de carros). Outro discurso que encontramos em comum nesses anúncios foi o de que a aceitação social ou pessoal está relacionada à aquisição e posse de objetos.

Nestes mesmos comerciais, os autores e a autora consideram que as mulheres são apresentadas de modo ofensivo, como se só se interessassem pelos homens por causa dos automóveis que eles possuem. No que diz respeito às imagens apresentadas diretamente às crianças, Nunes e Martins (2012) verificam que as novelas infantis, assim como outros artefatos da Cultura Visual, também sugerem e definem comportamentos próprios para cada gênero, e que as meninas e meninos tomam o cuidado para que tais ensinamentos sejam respeitados. Em outra pesquisa, em análise das capas dos cadernos dos/as estudantes das séries iniciais do Ensino Fundamental, Nunes (2010) verifica queaos garotos são endereçadas imagens de super heróis, esportes radicais, automóveis, velocidade e guerreiros históricos, e às garotas, por sua vez, projeções de moda, de vaidade, de animais de estimação, princesas, fadas, sereias e outras personagens fantásticas. Em diálogo com crianças, a autora presenciou resistência, principal- 
mente por parte dos meninos, quando sugeriu que admitissem que outras imagens pudessem estampar as capas de seus cadernos. Um dos meninos se posiciona dizendo:

a gente é menino, não é bichinha. Seria bichinha se tivesse desenho de menina, com caderno de cheirinho, brilho, adesivo que muda de posição. Isso é proibido para os meninos. É fora da lei! Esse caderno é proibido pros meninos, se não vão achar que ele é menina ao invés de menino. Meu próximo caderno tem que ser de carro, paraquedas ou heróis (NUNES, 2010, p. 88, grifo nosso).

Neste recorte da fala do estudante, especialmente duas questões nos chamam a atenção. A primeira é que o garoto assegura que, se porventura utilizasse caderno "de menina", seria confundido e apontado pelos/as outros/as como menina. Logo, para ele, mais do que um objeto, o caderno com imagens de carros, paraquedas ou heróis advém como um artefato que reforça sua masculinidade e sua macheza. A segunda questão destacada por nós é que a resistência em não se aproximar dos cadernos e demais elementos característicos do mundo feminino parece ser motivada menos por sua identificação com o caderno "de menino" e mais pelo medo do que os outros garotos poderiam pensar sobre ele.

Junqueira (2013) relaciona ações semelhantes a essas com a Pedagogia do Armário que consiste em movimentos de regulação e ajuste entre indivíduos para que esses não cruzem as fronteiras entre os gêneros. Esse controle é praticado, sobretudo, entre os homens já que são insistentemente cobrados para que não se "desviem" das ações e comportamentos esperados de um sujeito "macho". Prescrições como "homem não chora", "homem não dança", "homem não assiste novela", "homem não cozinha", "homem não pede ajuda", "homem não fofoca" e "homem não acha outro homem bonito" ainda são exemplos do controle e vigilância exercidos sobre e pelas masculinidades.

Ocorre que, por não conseguirem responder a todas as expectativas projetadas sobre eles, os homens e garotos buscam na Pedagogia do Armário meios de autenticar sua macheza. Mesmo que involuntariamente, sujeitos masculinos têm se ocupado em vigiar, controlar e ajustar os comportamentos de outros homens para que se mantenham coerentes àquilo que os reconhece enquanto homens. Isso porque, um homem que não atende aos ideais inatingíveis de macheza, 
[...] não tenderá a ter seu status questionado se agredir alguém considerado menos homem. Pelo contrário, com tais manifestações de virilidade, além de postular-se digno representante da comunidade dos "homens de verdade", ele poderá até ser premiado (JUNQUEIRA, 2013, p. 484).

Como podemos verificar na fala do menino citado por Nunes (2010), há preocupação e medo das piadas, das brincadeiras ofensivas e preconceituosas, da ridicularização e dos apelidos apontados por outros meninos que, possivelmente, enxergam ali uma oportunidade de escancarar que são "machos de verdade" em exercícios de "encontre o erro" (aqui, o "erro" é o "menos homem"). É importante ressaltar que não apenas os garotos exercem a Pedagogia do Armário, mas também os pais, as mães, as meninas, professoras, professores, entre outros/as. Quando concordam ou consentem às falas como "ande como macho" ou "sente como mocinha"7 estão elegendo certas ações como adequadas e sinalizando a necessidade de ajustar aquelas que se desviam do modelo. Em outras palavras, praticam a Pedagogia do Armário.

Moreno (2011) assevera que antes mesmo de frequentarem as instituições escolares, as crianças já aprenderam com sua família e amigos/as e com as imagens midiáticas o que é permissível aos meninos e às meninas. Todavia, a escola também tece suas contribuições para regular as identidades de gênero. O espaço e as brincadeiras escolares, assim como os materiais didáticos utilizados pelos/as docentes, contribuem para que a dicotomização entre os mundos masculinos e femininos seja ainda mais potencializada. É como se a organização escolar legitimasse que meninas pudessem ser fadas, enfermeiras e mães obcecadas pelos/as filhos/as, pelo almoço e pela limpeza da casa; e que os meninos pudessem ser policiais, tigres, bandidos e super-heróis. Essas representações são reforçadas e aprovadas à medida que os/as professores e professoras fazem uso de materiais didáticos que ilustram, por exemplo, "mulheres cozinhando e homens dirigindo" e "mulheres cuidando das crianças e homens praticando esportes".

O conjunto de autores e autoras citado nesse artigo investiga os ensinamentos que os artefatos da Cultura Visual exercem sobre gênero. Novelas, publicidades, capas de caderno e materiais didáticos reforçam os modelos hegemônicos de experimentar a masculinidade e a feminilidade. Nessas imagens, a localização dos gêneros "[...] é quase sempre carregada de estereótipos (rótulos) que colocam homens e mulheres 
dentro de 'caixas', ditando o que é adequado e o que é inadequado para cada um(a)" (BRASIL, 2011, p.12).

Tendo a corporação Kinder criado um produto para os meninos e outro para as meninas, também criou modelos de como ser homem e como ser mulher. Afinal, quais as representações que o Kinder Ovo constrói sobre masculinidade e feminilidade? No próximo item, dedicamo-nos às análises das imagens que permeiam o Kinder Ovo como artefato cultural que constrói e consolida os gêneros infantis.

\section{Carrinhos azuis e bonecas rosas: Pedagogia Kinder e a consolidação dos gêneros}

Segundo informações do site oficial da marca Kinder ${ }^{8}$, o Kinder Ovo ou Kinder Surpresa foi criado em 1974 e somente a partir de 1994 foi comercializado no Brasil. O chocolate, em formato de ovo, integra os muitos produtos criados e oferecidos pela corporação Kinder. Alegria, qualidade e confiança integram os valores principais da empresa. Junto à Nutella, Pralinas e Tic-tac ${ }^{9}$, a Kinder compõe as marcas da fundação Ferrero, iniciada pelo italiano Michele Ferrero (1925-2015) ${ }^{10}$.

Em 2013, quando lançou ovos de Páscoa azuis e rosas, com as palavras "meninos" e "meninas" estampadas em sua embalagem, a empresa apostou na segregação de gênero nos seus produtos comercializados em territórios brasileiros. A proposta foi criar produtos com cores e brinquedos específicos para cada um dos gêneros. Todavia, a iniciativa da empresa dividiu a opinião de consumidores e consumidoras que, em parte, consideraram-na sexista e preconceituosa. Frente às manifestações de internautas nas redes sociais, a Ferrero se pronunciou dizendo que a criação e divulgação das versões específicas para cada um dos gêneros foram baseadas "[...] em pesquisas feitas com mães e crianças, e criadas para atender às preferências dos consumidores" (G1, 2013, s/p).

Nos anos posteriores à polêmica, a Kinder intensificou a segregação de gêneros, aplicando-a em outros de seus produtos. Dentre eles o Kinder Ovo - produto que nos é especial pelos motivos apresentados nas considerações iniciais desse artigo. Em 2015, três produtos integraram a linha Kinder Ovo: O Kinder Ovo Natoons (cujas surpresas são animais), o Kinder Ovo Azul e o Kinder Ovo Rosa. É importante ressaltar que nossas análises foram feitas sobre as versões Rosa e Azul, do Kinder Ovo. A versão Natoons não foi contemplada por não ser destinada, especificamente, ao gênero feminino ou masculino. 
Em buscas que fizemos no site e na publicidade da empresa, selecionamos 13 imagens para compor o corpus de nossa análise. Destas, seis se referem à propaganda Deliciosa Surpresa (2015) e quatro são ilustrativas da embalagem com duas unidades do produto e que evidenciam alguns dos brinquedos que acompanham o chocolate Kinder. Como ferramenta para as análises de imagens, adotamos o Sistema Image Watching (OTT, 2011).

O sistema Image Watching é organizado em cinco categorias - descrevendo, analisando, interpretando, fundamentando e revelando - que atuam como procedimentos metodológicos para guiar e ampliar a sensibilidade visual. As etapas do Image Watching possibilitam que os objetos percebidos visualmente sejam nomeados e caracterizados (descrevendo); que relações entre eles sejam estabelecidas de modo a evidenciar aqueles que se destacam (analisando); que hipóteses e interpretações sejam levantadas como possíveis narrativas visuais (interpretando); que os conhecimentos sejam ampliados por meio da pesquisa (fundamentando); e que o aprendizado seja materializado em uma produção final (revelando) ${ }^{12}$.

Em nossa análise das Pedagogias Kinder, baseamo-nos também nos apontamentos feitos por Baliscei e Stein (2015) que, interessados pelos estudos de artefatos visuais, estabeleceram oito aproximações entre Estudos Culturais e Estudo da Cultura Visual - campos de investigação que também nos servem para a construção dos procedimentos metodológicos e analíticos desse artigo. Conforme os autores, tanto o Estudo da Cultura Visual quanto os Estudos Culturais:

1- Avaliam que as imagens da cultura popular precisam ser abordadas nas intervenções pedagógicas; 2- Não emitem olhares maniqueístas para os artefatos da cultura popular, isto é, não os consideram apenas positivos ou apenas negativos; 3- Orientam os/as professores/as a não utilizarem os elementos da cultura popular apenas por seu caráter hedonista; 4- Demonstram preocupação com o desenvolvimento da criticidade para se estudar as imagens; 5- Estimulam os/as professores/as a irem além dos estudos dos aspectos de composição das imagens; 6Evidenciam a importância de investigar os discursos intrínse$\cos$ às imagens da cultura popular; 7 - Entendem que uma mesma imagem pode ser interpretada de modos diferentes e, inclusive, opostos entre si; e 8- Consideram que as interpretações dizem respeito às características e conhecimentos dos sujeitos que interpretam (BALISCEI; STEIN, 2015, p.271). 
Ainda que digam respeito às análises pedagógicas dos artefatos da Cultura Visual, essas oito aproximações evidenciadas acima são enxergadas por nós como sugestões que guiam modos críticos de investigar os artefatos visuais também em pesquisas científicas.

A propaganda comercial intitulada Deliciosa Surpresa (2015), disponível no site oficial da marca ${ }^{13}$ e no Youtube ${ }^{14}$, apresenta como cena inicial um homem branco dirigindo. Quando estaciona o carro em frente a uma casa e abre o porta-malas, um menino de aproximadamente oito anos, provavelmente seu filho, corre para, finalmente, recebê-lo com um abraço saudoso (Figura 1 e 2). O menino é branco, loiro e veste camiseta azul e bermuda marrom. Em meio às frutas e às compras guardadas no porta-malas do carro, o menino encontra um saco plástico contendo água e um peixe dourado, os quais, na cena posterior, são exibidos por ele em meio a sorrisos de alegria e surpresa (Figura 3). Enquanto isso, a voz feminina de uma narradora ausente diz: "Existem aquelas surpresas que você prepara....
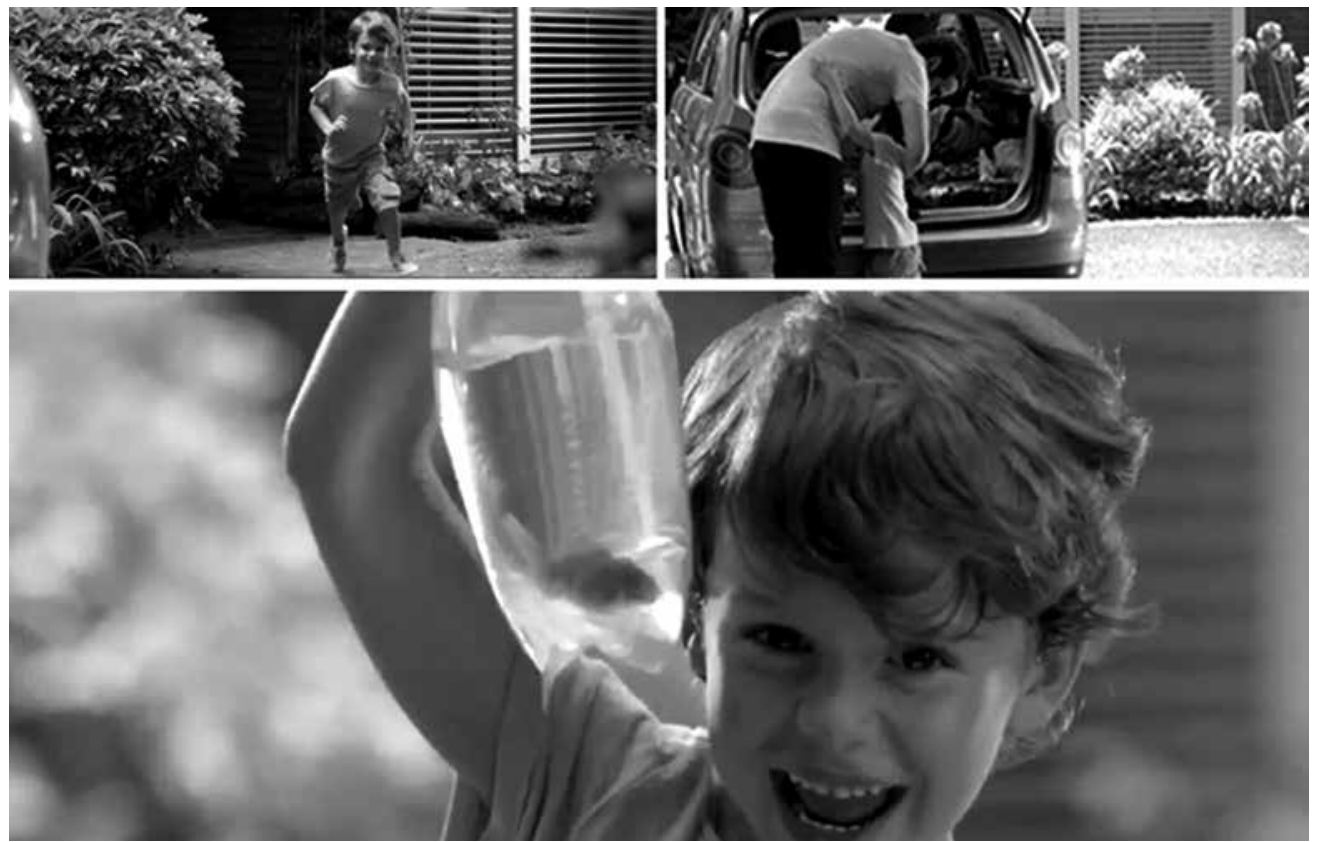

A cena seguinte retrata uma menina branca e de cabelos loiros e longos, com idade de aproximadamente oito anos, em um quarto decorado com bandeirinhas e brinquedos. Usando

Figuras 1, 2 e 3: “

Existem aquelas surpresas que você prepara..."

Fonte: Print screen do $1^{\circ}, 3^{\circ}$ e do 6o segundos do vídeo, 2015 . 

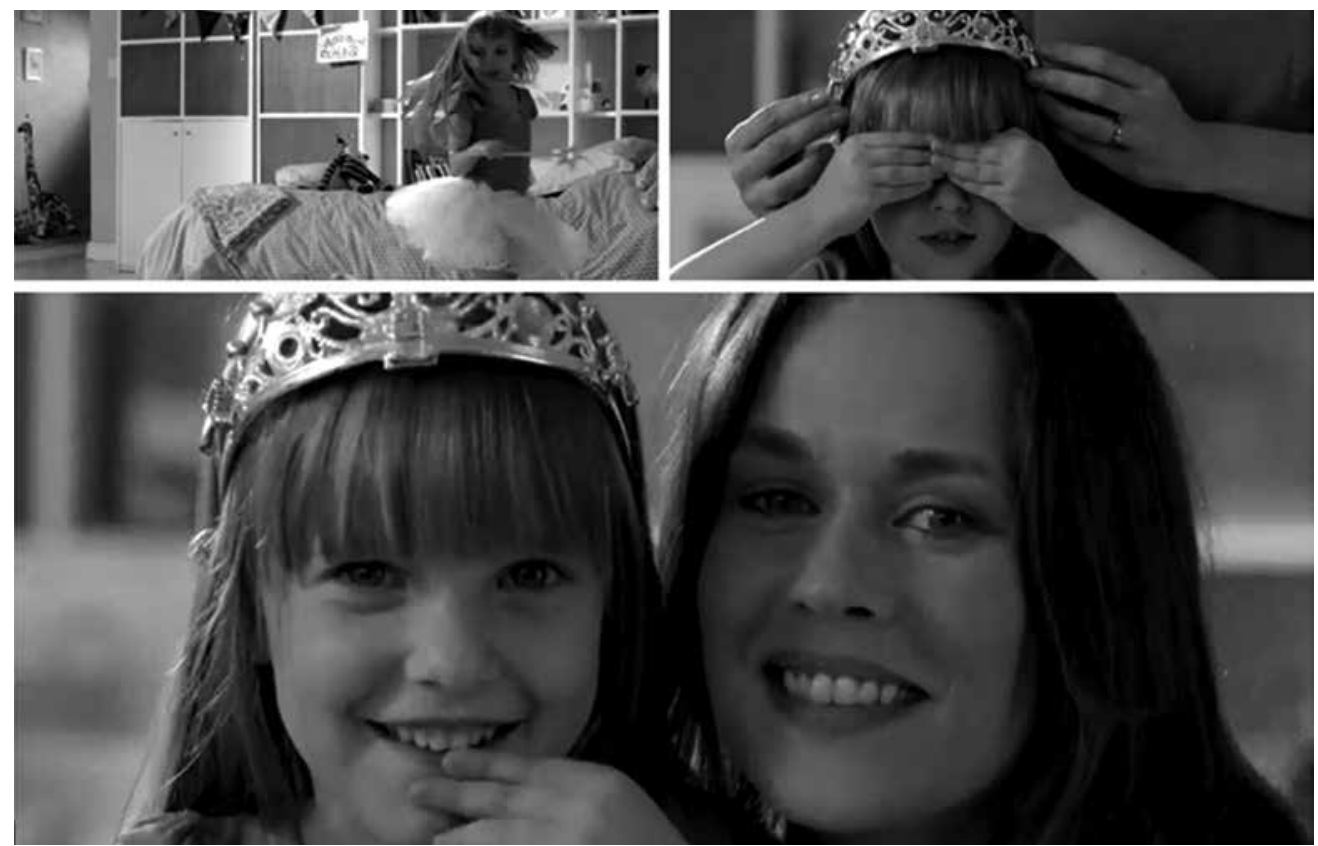

Figuras 4, 5 e 6 : "Não existem surpresas pequenas" Fonte: Print screen do $8^{\circ}$, $13^{\circ}$ e $15^{\circ}$ segundos do vídeo, 2015. camiseta rosa e saia volumosa característica das de bailarinas, a menina rodopia segurando uma varinha com uma estrela em uma de suas extremidades (Figura 4). Quando surpreendida por uma mulher branca, de meia idade, possivelmente sua mãe, a menina esconde seus olhos com as mãos e, posicionada em frente ao espelho, recebe em sua cabeça uma coroa prateada com pedras e adereços rosas (Figura 5). Mãe e filha sorriem, admirando seus reflexos no espelho (Figura 6). Enquanto a cena se desenvolve, a voz da narradora continua "[...] aquelas [surpresas] que trazem alegria [...] porque na verdade, para as crianças, não existem surpresas pequenas".

Já nas cenas finais da propaganda, ao mesmo tempo em que a menina e o menino brincam juntos na sala de estar, a mãe se aproxima trazendo escondidas em suas costas, duas unidades do produto Kinder Ovo, uma Rosa e a outra Azul, conforme a narradora completa "Só existem surpresas gostosas” (Figura 7). Em seguida, a mãe entrega o Kinder Ovo Rosa para a menina que demonstra surpresa em um "uau" de admiração (Figura 8). Mesmo não sendo explicitado, subtende-se que o Kinder Ovo Azul foi entregue para o menino. A última cena que envolve a família apresenta a mãe interagindo com o menino e menina que brincam, respectivamente, com uma moto e com uma boneca enquanto metade de seus chocolates 

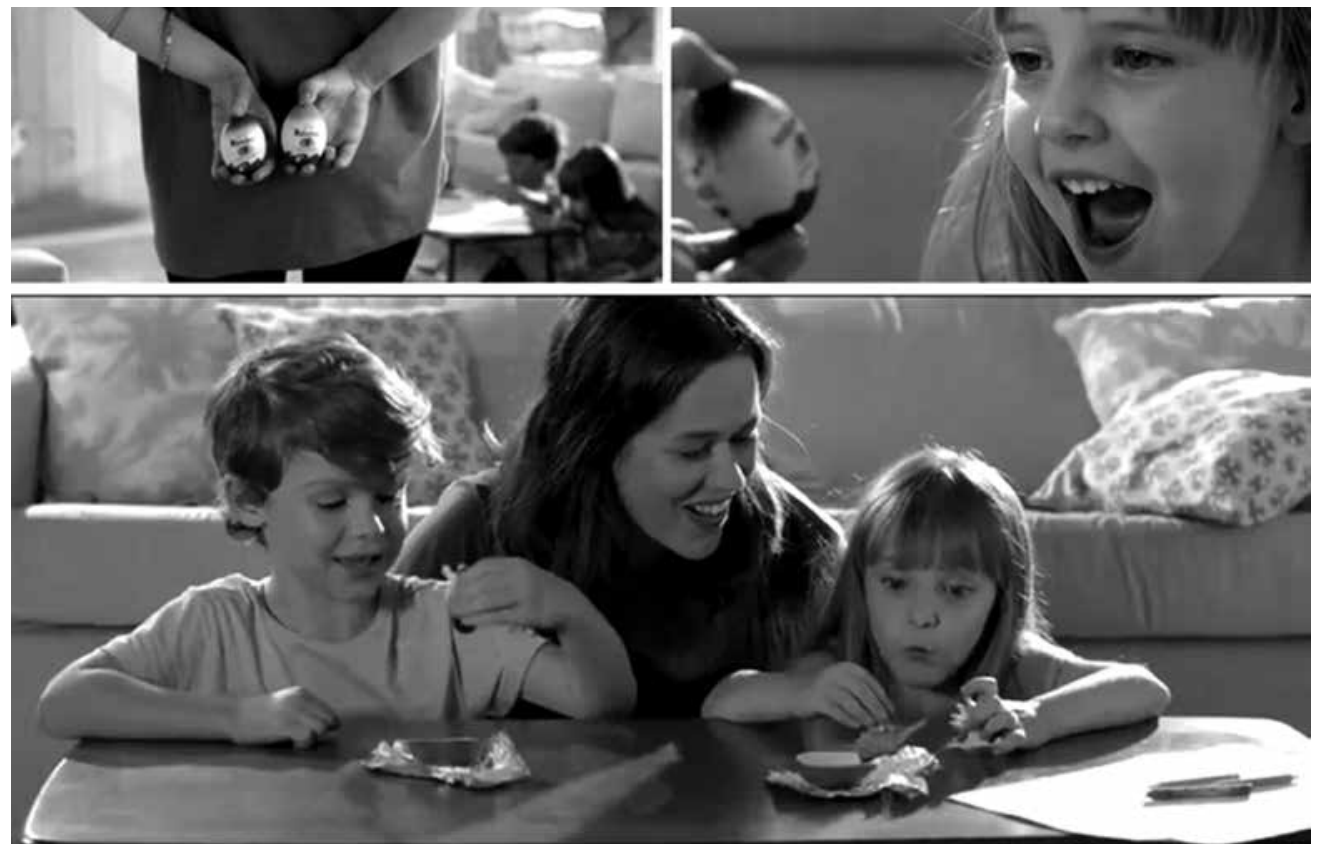

permanece intacta sobre a mesa (Figura 9). Intercalam-se a essas cenas, imagens do chocolate e de alguns dos brinquedos que o acompanham, assim como falas da narradora valorizando qualidades do produto e promovendo o slogan "Kinder Ovo, surpreender é delicioso".

Inferimos que o conjunto de cenas separadas e descritas legitima representações de uma família patriarcal, de classe média, branca e fruto de uma união heterossexual, cujos valores sugerem pertencer à cultura hegemônica da sociedade ocidental (SCHOR, 2009; STEINBERG; KINCHELOE, 2001). A primeira personagem a aparecer, o pai, configura apenas as cenas de ambiente externo, o que reforça as representações atribuídas ao homem, como o interesse por automóveis e pelo trabalho intelectual, assim como responsabilidade pelo sustento financeiro da família. O menino é a única das crianças apresentada em ambiente externo e também o único membro da família que se relaciona com o pai solidificando as inferências de Schor (2009, p. 40) de que, na publicidade, “[...] garotas são mais fotografadas em ambientes domésticos, enquanto os garotos são mostrados em áreas externas".

Na propaganda Deliciosa Surpresa (2015), pai e filho se abraçam em frente ao carro, símbolo de masculinidade, como se, com isso, selassem a cumplicidade "garantida" pela 
semelhança de gênero. Ainda que enobreçam os valores da família, para nós, tais imagens consolidam e perpetuam uma estrutura patriarcal que,

[...] firma sérias implicações para a mulher, mas também deturpa o desenvolvimento masculino. Meninos são encorajados de várias formas, no currículo da cultura infantil, a assumir papéis patriarcais que lhes são legados por direito de nascença, para definir a realidade e aproveitar completamente as recompensas do privilégio de sua dominação sobre seus subordinados (STEINBERG; KINCHELOE, 2001, p. 46).

A estratégia de segregar os mundos masculinos e femininos é exercida pela Pedagogia Kinder não somente quando distribui os brinquedos em cápsulas e embalagens separadas para meninos e meninas. A propaganda, como artefato da Cultura Visual também reforça os contornos entre os gêneros quando induz, por exemplo, que os homens devem trabalhar/viver fora de casa e ter posse de conhecimentos e habilidades com automóveis.

A mãe, por sua vez, figura as cenas cujos cenários são ambientes internos. Quarto, banheiro e sala de estar são os espaços ocupados pelas mulheres nessa propaganda que "naturaliza" os papéis e funções femininas. Além disso, as imagens destacam cuidados e preocupações que a mãe precisa adotar com seu filho e filha, como se somente ela fosse responsável pela educação, saúde e alimentação das crianças. Diferente do pai que é recebido pelo menino, é a mãe que se dirige à filha $\mathrm{e}$ ao filho, (primeiramente à menina, em seu quarto e, posteriormente, a ambos enquanto estudam na sala). Para nós, fixar a mulher em papéis exclusivos de mãe e dona de casa consolida a representação fortalecida pelo senso comum machista de que as meninas são menos suscetíveis à ambição de serem bem-sucedidas profissionalmente e que se satisfazem em ofícios domésticos e cuidados com a saúde (MORENO, 2011; NUNES, 2010; SCHOR, 2009). Para Schor (2009, p. 41) "[...] quando realizações e poder são mostrados nos comerciais, os meninos são geralmente os alvos", enquanto que "[...] os sentimentos de docilidade, de amizade e de ternura são moldados como algo inerente ao feminino" (NUNES, 2010, p. 80).

Amizade e docilidade podem ser percebidas nos afetos trocados entre mãe e filha. Semelhante à relação entre o pai e o filho, sobre a qual discutimos anteriormente, na cena em que estão no banheiro em frente ao espelho, as mulheres parecem compartilhar de interesses próximos. Ambas se vestem com 
roupas em tons rosados e vislumbram suas imagens refletidas no espelho. Assim como os homens e meninos precisam recorrer à virilidade, à força e à razão para terem sua "macheza" reconhecida culturalmente, as mulheres e meninas são cobradas, principalmente, para que demonstrem apreensão obsessiva pela aparência e pela beleza. As imagens televisivas, o material escolar e, inclusive as personagens dos produtos e animações da Disney contribuem para que colemos ao corpo feminino características exageradas (GIROUX, 2001; BALISCEI; 2015). Não é por acaso que, na cultura machista em que vivemos, espera-se que as mulheres insistentemente busquem pela magreza, beleza e sensualidade. No meio publicitário, essas projeções e movimentos produzidos pela Pedagogia Kinder se desdobram em fotografias de meninas de dez, oito, seis anos deformando-se em caras e poses altamente eróticas, sexuais e sedutoras, como se fossem "pequenas lolitas" (ANDRADE; COSTA, 2010, p. 244).

Analisamos ainda que a narrativa da propaganda insinua que há uma boa relação entre as diferentes gerações. A diferença de idade, assim como a dos interesses de crianças e adultos não aparentam ser obstáculos para a amizade entre eles/as. As diferenças entre os gêneros, por outro lado, parecem funcionar como barreiras que dividem mundos e impossibilitam trocas. Ainda que incentivem relações intergeracionais, as imagens e cenas analisadas por nós, quase nada apresentam sobre a relação mãe-filho, pai-filha, filho-filha e pai-mãe. Eles/as não se abraçam, não se tocam e nem se olham. Vemos a mãe carregando em suas mãos o Kinder Ovo Azul com o qual o menino posteriormente brinca, todavia, não nos é mostrado como ela o entregou a ele. Houve sorriso e trocas de olhares? Abraços, talvez? Ou será que a mãe pediu para que a menina o entregasse? Além disso, a espontaneidade das relações intergeracionais e os desconfortos das relações entre pessoas de gêneros diferentes são expressados também na cena final em que a família, sem o pai, reúne-se em volta do Kinder Ovo Azul e Rosa.

Enquanto as crianças interagem com seus brinquedos sobre a mesa, a mãe sorri e desloca seu rosto e olhar unicamente para a filha. Ainda que singelo, o gesto pode ser interpretado como sinal da afinidade que a mãe tem pela filha e pelo mundo feminino, ou como reflexo de sua inabilidade para participar e lidar com as "coisas de menino", ou ainda, indício de seu interesse pelo Kinder Ovo Rosa que, por ser "para meninas" também é endereçado à ela. Independente das interpretações, para nós, ela se acrescenta às outras sutilezas que demarcam terrenos e territórios próprios de cada gênero. 

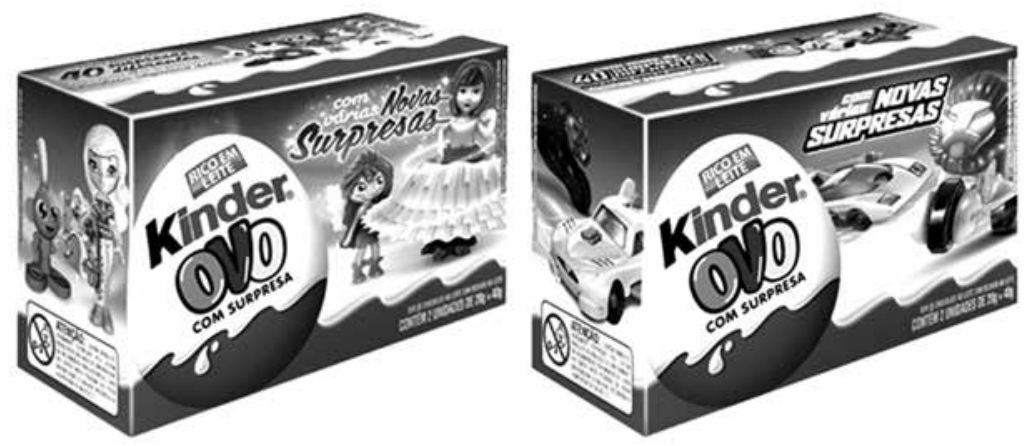

Figuras 10 e 11 Duas caixas e infinitas surpresas Fonte: Imagens selecionadas no site oficial do produto <http:// www.kinder.com.br/pt/kinder-surpresa>. Acesso em: o6 maio 2015 .
Além da propaganda Deliciosa Surpresa (2015), analisamos um segundo artefato da Cultura Visual da marca Kinder: as embalagens que acondicionam o ovo de chocolate e a surpresa Kinder. A caixa do Kinder Ovo Rosa é composta, primordialmente por tons rosados e brinquedos atribuídos às meninas, e o Kinder Ovo Azul, de caixa com tons azulados, exibe brinquedos conferidos aos meninos (Figura 10 e 11, respectivamente).

Além das informações nutricionais, da gramatura e das propriedades do chocolate, são estampadas nas caixas retangulares imagens, cores e formas que exercem o que aqui denominamos de Pedagogia Kinder. Pedagogia sexista que, por meio das visualidades, estabiliza e rejeita modos de viver a feminilidade e a masculinidade. Encontramos em Farina, Perez e Bastos (2006) subsídios para conceituar a Pedagogia Kinder. Argumentam que,

as qualidades atribuídas à cor rosa são consideradas tipicamente femininas. [A cor] Simboliza o encanto, a amabilidade. Remete à inocência e frivolidade. Feminino. É uma cor terna e suave muito utilizada em associações com o público infantil, principalmente às meninas (FARINA; PEREZ; BASTOS, 2006, p. 105).

Os tons azulados, por sua vez, denotam seriedade, tranquilidade, razão e sabedoria, qualidades socialmente esperadas no comportamento de homens e meninos. Nas faces das duas caixas foram impressas frases como "com várias novas surpresas" e "com mais de 40 surpresas diferentes para vários tipos de brincadeiras". Uma questão importante a ser evidenciada em nossa análise é que, ainda que as frases sejam iguais, as caixas apresentam distinções entre meninos e meninas por meio das cores e do design da caligrafia. Quanto às cores, na embalagem do Kinder Ovo Rosa (Figura 12), as frases são com- 

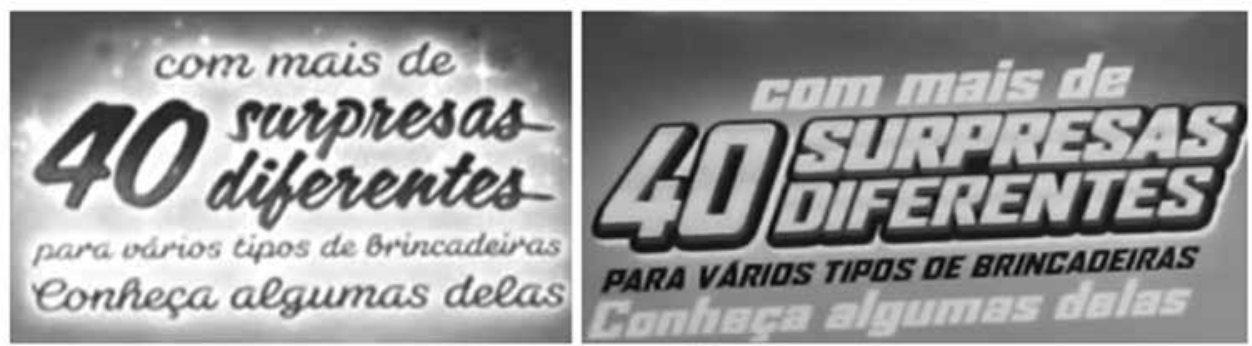

postas por tons lilases e roxos que provocam associações com magia, fantasia, delicadeza e mistério. As cores prata e preto, presentes nas frases do Kinder Ovo Azul (Figura 13), carregam sentido de tecnologia, sofisticação, modernidade, seriedade e requinte (FARINA, PEREZ e BASTOS, 2006).

Quanto ao design, Chinem (2005, p. 10) analisa que "[...] linhas retas, ângulos e vértices estão associados à rigidez, à firmeza e à masculinidade. Curvas e ondulações expressam dinamicidade, sensualidade e feminilidade". Essas estratégias se materializam também nas imagens produzidas pela Pedagogia Kinder. As letras do produto destinado às meninas são engendradas por linhas curvadas, espiraladas e mais fluídas que convergem para o efeito de arredondamento (FILHO, 2000), enquanto que linhas quebradas, retas e com arestas marcadas constituem as letras do produto direcionado aos meninos.

Além de apresentar essas informações, essas embalagens trazem imagens de brinquedos-surpresas que acompanham o ovo de chocolate. Neste caso, mais explicitamente do que no design das letras, há diferenças e segregações entre as expectativas e atribuições feitas aos meninos e às meninas. Nas costas das caixas dez brinquedos são divididos e intitulados em grupos. No caso do Kinder Ovo Rosa, os títulos empregados foram "Piões e bolas", "Para colorir", "Bichinho", "Bonecas" e "Acessórios". No caso do Kinder Ovo Azul, os títulos são "Monstros e dragões", "Piões e bolas" e "Carros, motos e bicicletas".

Dos sete grupos, apenas um deles é comum entre o Kinder Ovo Rosa e o Azul, aquele constituído por "Piões e bolas" - brinquedos associados culturalmente aos meninos. Com isso, a Pedagogia Kinder valida e fortalece compreensões de que meninos não podem brincar com bonecas, com materiais escolares e com acessórios de moda. Ao contrário disso, precisam se distanciar daquilo que é rosa, macio, brilhante e delicado. Como destacado por Schor (2009) em comerciais e publicidades destinadas aos meninos, evitam-se cenas com
Figuras 12 e 13

"Com várias Novas surpresas" Fonte: Print screen do 10 segundo do vídeo disponibilizado no Youtube <https://www.youtube. com/watch? $v=E B X r_{7} 3$ w Iv1k $>e$ print screen do $14^{\circ}$ segundo do vídeo disponibilizado no Youtube $<$ https://www.youtube.com/ watch? $v=v Z M V U V M p y d s>$. Acesso em: o6 maio 2015 . 
atrizes meninas. Quando elas aparecem, certamente, estão em minoria e ocupam papéis secundários, coadjuvantes. Isso porque os garotos são cobrados a manter sua identidade de gênero bem definida e a não demonstrarem publicamente suas emoções e sentimentos, e muito menos suas "possíveis" inclinações pelos gostos e objetos femininos (STEINBERG; KINCHELOE, 2001).

No corpus de nossa análise, integrado por 13 imagens da marca Kinder, verificamos que as representações de gênero são bastante próximas e semelhantes daquelas em circulação pelos meios de comunicação e cultura popular. Propagandas, cores, design de caligrafias, brinquedos e embalagens convergem em seus discursos sobre masculinidade e feminilidade e contribuem para que as crianças se localizem e sejam localizadas nos "limites" de sua identidade de gênero. Antes de tecermos nossas considerações finais, vale esclarecer que, quando analisamos as pedagogias presentes nas imagens do Kinder Ovo Rosa e Azul, não desempenhamos crítica direta e exclusiva à empresa Kinder, pois consideramos que não é determinada marca ou produto por si só que forma(ta) as infâncias.

Quando elegemos as imagens da Pedagogia Kinder para nossa análise, pretendemos evidenciar que é possível questionar, investigar e, inclusive, discordar daquilo que nos interpela. Diante de ensinamentos como, "meninos devem brincar de carrinhos" e "meninos não demonstram afeto", não precisamos expressar consentimento e concordância. Nossa reflexão se posiciona como um grande 'SERÁ?' frente às imagens que dizem como devemos viver e experimentar nossa masculinidade e feminilidade.

\section{Considerações finais}

O título deste artigo se refere à participação das imagens da Cultura Visual na construção e manutenção das infâncias, principalmente no que diz respeito às identidades de gênero. Para viverem a diversidade de seu gênero e aproveitarem os prazeres que ela proporciona, muitas vezes, meninos e meninas precisam desempenhar aquilo que aqui denominamos de Pedagogias do Disfarce. Nela, mascaram-se gostos e preferências para que suas diferenças não sejam publicamente apontadas e ridicularizadas.

Os critérios que decidem o que deve ser aprovado e o que deve ser ajustado são construídos principalmente nos territórios culturais. Assim, sons, vídeos, gestos, movimentos e 
principalmente imagens são meios de se garantir que determinadas vozes sejam ouvidas e que outras sejam silenciadas. Muitas das imagens e representações que integram a Cultura Visual são produzidas e comunicadas pelas corporações e empresas de produtos infantis. Motivados/as por nossas memórias pessoais e pelos interesses que manifestamos pelas infâncias pós-modernas, problematizamos a constituição de gênero por meio dos discursos promovidos pelos artefatos culturais infantis. Quais as representações que o Kinder Ovo cria sobre masculinidade e feminilidade?

No corpus de nossa análise, integrado por 13 imagens de artefatos da Cultura Visual, investigamos representações de gênero circuladas e idealizadas pela propaganda, brinquedos, cores, design e embalagens da Pedagogia Kinder. Como resultado, inferimos que as imagens sobre masculinidade provocam associações com velocidade, adrenalina, força, dinamicidade, competição, movimento, batalhas, perigo, exploração e com os ambientes externos. Por sua vez, as imagens sobre feminilidade destacam a vaidade, a beleza, moda, romantismo, vestuário, habilidades e técnicas artísticas, delicadeza, passividade, introspecção, meiguice e os ambientes internos.

Ainda que as relações entre indivíduos e imagens sejam sempre assimétricas, marcadas pela negociação e ressignificação de conteúdos, para nós, quando insiste em oferecer representações cristalizadas, a Pedagogia Kinder ratifica padrões de ser menino e ser menina, apresentando às crianças pós-modernas modos restritos e simplificados de viverem suas infâncias e suas identidades de gênero.

Com isso, semelhante às representações estereotipadas, a Pedagogia Kinder invisibiliza (ou ao menos dificulta o acesso às) possíveis combinações e nuances entre os múltiplos aspectos masculinos e femininos. Ao eleger tais imagens para nossa análise, compreendemo-las como produtos e produtoras das Pedagogias Culturais que nos localizam e enquadram em caixas apertadas, cujas paredes sólidas, para serem desestabilizadas, exigem contínuos movimentos de questionamento e problematização. Assim como cimento, a cultura alicerça e fortalece paredes tão rígidas que, para movê-las, são necessários planejamento, persistência, autoavaliação e movimentos curtos, porém insistentes.

Desestabilizar paredes, indagar sobre o que se tem por naturalizado e provocar incômodos, foram nossas intenções quando, nesse artigo, problematizamos a Pedagogia Kinder e a construção visual dos gêneros e das infâncias. Pelas informações 
estampadas nas embalagens do produto, sabemos que são mais de 40 brinquedos que constituem a coleção de surpresas do Kinder Ovo Rosa e Azul. Quantos desses brinquedos são comuns aos meninos e meninas? São compostos pelas mesmas cores? Os brinquedos desenvolvem capacidades e habilidades semelhantes? Quantos brinquedos femininos fazem referência à coragem e velocidade? Interromper essa discussão com perguntas - e não respondê-las - é, para nós, um artifício para destacar que ainda existem muitas paredes sólidas e que, para desestabilizá-las, são necessários outros movimentos de pesquisa e questionamento.

\section{NOTAS}

1. Trecho da música Super Homem (a canção), de composição de Gilberto Gil (1942 --), que nos inspira na discussão sobre as múltiplas combinações entre os gêneros. Disponível em: <http://www.vagalume.com.br/caetano-veloso/super-homem-a-cancao.html>. Acesso em: 5 maio 2015.

2. Por ter iniciado com relatos sobre minha infância, neste primeiro momento, recorro à conjugação de verbos na primeira pessoa do singular para, posteriormente, incluir outros olhares e vozes em conjugações no plural.

3. Na ocasião, Educação Artística era o nome pelo qual nos referíamos à disciplina de Arte - área esta, na qual lecionei junto às séries do Ensino Fundamental e Médio por três anos e atualmente leciono no Ensino Superior.

4. Como outras crianças, muitas vezes, eu recorria à cápsula e ao brinquedo antes mesmo de ter experimentado o chocolate.

5. A partir deste momento, conjugamos os verbos no plural como marcação do nosso entendimento de que a pesquisa científica é uma construção coletiva e que aos nossos olhares são sobrepostos olhares obtidos em, por exemplo, filmes, livros, nas falas de professores e professoras, nos pensamentos de autores e autoras (CORAZZA, 2007).

6. Aqui propositalmente não flexionamos o termo parceiras em "parceiros", entendendo que, culturalmente a heterossexualidade é considerada norma e modelo, mistificando e invisibilizando as demais maneiras de se viver a sexualidade.

7. Tais falas-ajustes soam tão naturais, que empregamos tonalidade agressiva de ordem em "ande como macho", e tom doce e delicado de recomendação em "sente como mocinha".

8. < http://www.kinder.com.br/>. Acesso em: o6 maio 2015.

9. Empresas que comercializam creme de avelã, chocolates e pastilhas comestíveis, respectivamente.

10. Informações disponíveis no site oficial da fundação Ferrero no Brasil <http://www.ferrero.com.br/a-nossa-historia>. Acesso em: o7 maio 2015.

11. A elaboração desse artigo manifesta-se na etapa revelando (OTT, 2011), uma vez que responde aos conhecimentos e saberes produzidos em nosso exercício de análise de imagens.

12. < http://www.kinder.com.br/pt/kinder-surpresa>. Acesso em: o6 maio 2015 . 
13. < https://www.youtube.com/watch?v=iys9U8mFDkA>. Acesso em: o6 maio 2015 .

\section{Referências}

ANDRADE, Paula Deporte de; COSTA, Marisa Vorraber. Usando crianças para vender: infâncias e consumo na publicidade de revistas. Revista Reflexão e Ação, Santa Cruz do Sul, v.18, n. 2, p.230-248, jul./dez. 2010.

BALISCEI, João Paulo. Cultura visual e representações de gênero: o que os filmes da Disney dizem sobre meninos e meninas? In: Pedagogia 2015: Encuentro Internacional por la Unidad de los Educadores, 2015, Havana. Memorias: Pedagogia 2015: Encuentro Internacional por la Unidad de los Educadores, 2015.

BALISCEI, João Paulo; STEIN, Vinícius. Como olhamos e somos olhados pelas imagens? Estudos críticos dos artefatos da cultura visual. Revista Reflexão e Ação, Santa Cruz do Sul, v.23, n.1, p.251-275, jan./jun. 2015.

BALISCEI, João Paulo. STEIN, Vinícius; CHIANG, Chih Wei. Marcas na pele: reflexões sobre tatuagem, identidade e escolarização pós-moderna. Revista digital do $L A V$, Santa Maria, v.8, n. 3, p. 28-47, set./dez. 2015. Disponível em: $<$ http://cascavel.ufsm.br/revistas/ojs-2.2.2/index.php/revislav/article/view/19673 >. Acesso em: 14 mar. 2016.

BALISCEI, João Paulo; TERUYA, Teresa Kazuko; STEIN, Vinícius. Como "ser homem"? Investigando discursos sobre masculinidades. Revista digital do LAV, Santa Maria, v. 8, n. 4, p.88-104, jan./abr. 2015.

BRAGA, Eliane Rose Maio. Gênero, sexualidade e educação: Questões pertinentes à pedagogia. In: CARVALHO, Elma Júlia Gonçalves de; FAUSTINO, Rosângela Célia. (Org.). Educação e diversidade cultural. Maringá: Eduem, 2010. p. 205-218.

BRASIL. Ministério da Saúde, Secretaria de Vigilância em Saúde. Departamento de DST/AIDS e Hepatites Virais. Adolescentes e Jovens para a Educação entre Pares: Gêneros. - Brasília: Ministério da Saúde, 2011.

CHINEM, Marina Jugue. As variantes sígnicas da embalagem: as relações da percepção no processo intersemiótico na construção dos estímulos táveis e visuais. In: XXVIII Congresso Brasileiro de Ciências da Comunicação - INTERCOM, 2005. As variantes sígnicas da embalagem: as relações da percepção no processo intersemiótico na cons- 
trução dos estímulos táveis e visuais, 2005. v. 4. <http:// www.portcom.intercom.org.br/pdfs/124603330325699863 853199878311524296455.pdf $>$. Acesso em: o7 maio 2015.

CORAZZA, Sandra Mara. Labirintos da pesquisa, diante dos ferrolhos. In: COSTA, Marisa Vorraber (Org.). Caminhos investigativos I: Novos olhares na pesquisa em educação. 3. ed. Rio de Janeiro: Lamparina, 2007. p.103-127.

COSTA, Marisa Vorraber. Quem são, que querem, que fazer com eles? Eis que chegam às nossas escolas as crianças e jovens do século XXI. In: MOREIRA; Antonio Flávio; GARCIA, Regina Leite; ALVES, Maria Palmira. (Org.). Cultura, cotidiano e tecnologias. Araraquara (SP): Junqueira \& Marin, 2006, p. 93-109.

CUNHA, Susana Rangel Vieira da. Entre Van Goghs, Monets e Mônicas: a infância educada através de imagens. Ciências e Letras, n. 43, p. 107-123, jan./jun., 2008.

CUNHA, Susana R. Vieira da. As Transformações da imagem na literatura infantil. In: PILLAR, Alice Dutra (Org.). A educação do olhar no ensino das artes. Porto Alegre: Mediação, 2011. p.129-141.

CUNHA, Susana Rangel Vieira da. Questionamentos de uma professora de arte sobre o ensino de arte na contemporaneidade. In: MARTINS, Raimundo; TOURINHO, Irene. Cultura das imagens: Desafios para a arte e para a educação/ Raimundo Martins e Irene Tourinho (Org.). Santa Maria: Editora UFSM, 2012, p.99-123.

CUNHA, Susana Rangel Vieira da. Imagens como pedagogias culturais em cenários da educação infantil. In: MARTINS, Raimundo; TOURINHO, Irene. Pedagogias culturais. Santa Maria: Editora UFSM, 2014. p.199-223.

EVANGELISTA, O. Apontamentos para o trabalho com documentos de política educacional. In: ARAÚJO, Ronaldo Marcos de Lima ; RODRIGUES, Doriedson S. (Org.). A pesquisa em trabalho, educação e políticas educacionais. 1. ed. Campinas-SP: Alínea, 2012, v. 1. p. 52-71.

FARINA, Modesto; PEREZ, Clotilde; BASTOS, Dorinho. Psicodinâmica das Cores em Comunicação. 5. ed. rev. e ampl. São Paulo: Edgard Blücher, 2006. 173 p.

FILHO, João Gomes. Gestalt do Objeto: sistema de Leitura Visual da Forma. São Paulo: Escrituras, 2000.

G1. "Após ser chamado de sexista, Kinder Ovo diz respeitar diferentes opiniões". G1 - 12 de março de 2013. Disponível em: < http://g1.globo.com/economia/midia-e-marketing/ noticia/2013/o3/apos-ser-chamado-de-sexista-kinder-ovo-diz-respeitar-diferentes-opinioes.html>. Acesso em: 
07 maio 2015.

GIROUX, Henry. Os filmes da Disney são bons para seus filhos? In: STEINBERG, Shirley R.; KINCHELOE, Joe L. (Org.) Cultura infantil: a construção corporativa da infância. Tradução de George Eduardo Japiassú Bricio. Rio de Janeiro: Civilização Brasileira, 2001. p. 89-108.

HERNÁNDEZ, Fernando. Cultura visual, mudança na educação e projetos de trabalho. Porto Alegre: ArtMed, 2000, $262 \mathrm{p}$.

HERNÁNDEZ, Fernando. Catadores da cultura visual: transformando fragmentos em nova narrativa educacional. Tradução de Ana Duarte. Porto Alegre: Mediação, 2007.

JUNQUEIRA, Rogério Diniz. Pedagogia do armário: a normatividade em ação. Retratos da Escola , v. 7, p. 481-498, 2013.

LOURO, Guacira Lopes. O corpo educado: pedagogias da sexualidade. Belo Horizonte: Autêntica, 2000.

LOURO, Guacira Lopes. Gênero e sexualidade: pedagogias contemporâneas. Pro-Posições, , Campinas, São Paulo, v.19, n. 2, p.17-23, ago. 2008.

MORENO, Monsterrat. Como se ensina a ser menina: sexismo na escola. Editora Unicamp, 2011.

MOMO, Mariângela. Infância e escola no espaço-tempo do consumo. In: KIRCHOF, Edgar Roberto; WORTMAN, Maria Lúcia; COSTA, Marisa Vorraber (Org.). Estudos Culturais educação: contingências, articulações, aventuras, dispersões. Canoas: Editora ULBRA, 2015, p. 93-114.

MOMO, Mariangela; COSTA, Marisa Vorraber. Crianças escolares do século XXI: para se pensar uma infância pós-moderna. Cad. Pesqui. [online]. 2010, v. 40, n. 141. p. 965-991.

NUNES, Luciana Borre. As Imagens que invadem as salas de aula: reflexões sobre cultura Visual. 1. ed. São Paulo: Ideias \& Letras, 2010. 126 p.

NUNES, Luciana Borre; MARTINS, Raimundo. “Esse é o jeito rebelde de ser": produzindo masculinidades nas salas de aula. Revista Digital do $L A V$, v. 8, p. 3, 2012.

OLIVEIRA, Marilda Oliveira de. Minha trajetória na formação inicial. In:_ _ ; HERNÁNDEZ, Fernando. (Org.). A formação do professor e o ensino das artes visuais. Santa Maria: Editora UFSM, 2005. p. 23-42.

OTT, Robert William. Ensinando crítica nos Museus. In: BARBOSA, Ana Mae (Org.). Arte-educação. Leitura no subsolo. 8. ed. São Paulo: Cortez, 2011.

SCHOR, Juliet B. Nascidos para comprar: uma leitura essencial para orientarmos nossas crianças na era do consumismo. Tradução de Eloisa Helena de Souza Cabral. São Paulo: 
Gente, 2009.

SILVA, Tomaz Tadeu da. Teoria cultural e educação: um vocabulário crítico. Belo Horizonte: Autêntica, 2000. 128 p.

SOUZA, Michely Calciolary; BALISCEI, João Paulo; TERUYA, Teresa Kazuko. Representações visuais na modernidade líquida: o que os manequins falam de nós? Revista Educação da UFSM, Santa Maria, v. 40, n 2, p. 361-374, maio./ ago. 2015. Disponível em: <http://cascavel.ufsm.br/revistas/ojs-2.2.2/index.php/reveducacao/article/view/14198>. Acesso em: 10 jan. 2016.

STEINBERG, Shirley R; KINCHELOE, Joe L. Sem segredos: cultura infantil, saturação de informação e infância pós-moderna. In: (Org.). Cultura infantil: a construção corporativa da infância. Tradução de George Eduardo Japiassú Bricio. Rio de Janeiro: Civilização Brasileira, 2001. p. 9-52. TERUYA, Teresa Kazuko; BALISCEI, João Paulo; NASCIMENTO, Mariana Costa do. Trabalho docente na Modernidade Líquida: O Prezi no processo ensino e aprendizagem dos/ as "alunos/as surfistas". Revista Contrapontos, v.15, n.1, p.111-121, jan./abr. 2015.

TOURINHO, Irene; MARTINS, Raimundo. Investindo no potencial das pedagogias culturais... In: MARTINS, Raimundo; TOURINHO, Irene (Org.). Pedagogias Culturais. Santa Maria: Editora UFSM, 2014, p. 11-14.

VEIGA-NETO, Alfredo. Olhares... In: COSTA, Marisa Vorraber (Org.). Caminhos investigativos I: Novos olhares na pesquisa em educação. 3. ed. Rio de Janeiro: Lamparina, 2007. p. 23-38.

Recebido em: 09/07/15

Aceito em: 19/04/16 


\section{JOÃO PAULO BALISCEI}

\section{vjbaliste@gmail.com}

É Mestre em Educação (2014) pelo Programa de Pós-Graduação da Universidade Estadual de Maringá (UEM). Atualmente é professor no curso de Artes Visuais na Universidade Estadual de Maringá e doutorando no Programa de Pós-Graduação em Educação da referida instituição.

\section{ELIANE ROSE MAIO \\ elianerosemaio@yahoo.com.br}

Possui Doutorado em Educação Escolar pela Universidade Estadual Paulista (UNESP/Araraquara) (2008), Pós-Doutorado em Educação Escolar na UNESP/Araraquara, com a temática da Trajetória da Educação Sexual no Brasil. É professora da Universidade Estadual de Maringá (UEM), no Departamento de Teoria e Prática da Educação e do Programa de Pós-Graduação em Educação (PPE).

\section{GEIVA CAROLINA CALSA gccalsa@hotmail.com É Doutora em Educação pela Universidade Estadual de Campinas (Unicamp) (2002). Atualmente é professora adjunta da Universidade Estadual de Maringá (UEM), no Departamento de Teoria e Prática da Educação e do Programa de Pós-Graduação em Educação (PPE).}

